\title{
Pharmacological Study on Some New 3-[(1-Methylpyrrol-2-yl)- methyl]-4-Substituted 4,5-Dihydro-1H-1,2,4-triazol-5-ones
}

\author{
Monika Pitucha ${ }^{\mathrm{a}, *}$, Anna Chodkowska ${ }^{\mathrm{b}}$, Renata Duda ${ }^{\mathrm{b}}$, \\ and Ewa Jagiełło-Wójtowicz ${ }^{\mathrm{b}}$ \\ a Department of Organic Chemistry, Medical University, Staszica 6, 20-081 Lublin, Poland. \\ E-mail: monika.pitucha@am.lublin.pl \\ b Department of Toxicology, Medical University, Chodźki 8, 20-093 Lublin, Poland \\ * Author for correspondence and reprint requests \\ Z. Naturforsch. 64c, 615-618 (2009); received June 9, 2009 \\ 3-[(1-Methylpyrrol-2-yl)methyl]-4-substituted 4,5-dihydro-1H-1,2,4-triazol-5-ones were ob- \\ tained by the cyclization reaction of 1-[(1-methylpyrrol-2-yl)acetyl]-4-substituted semicar- \\ bazides in alkaline medium. The effects of the synthesized compounds of the central nervous \\ system of mice were studied.
}

Key words: 1,2,4-Triazol-5-one, Pharmacological Screening

\section{Introduction}

Triazoles and their heterocyclic derivatives represent an interesting class of compounds possessing a wide spectrum of pharmacological activities. Depending on the type of substituents these can show various biological activities such as anticonvulsant (Kane et al., 1990), analgesic (TuranZitouni et al., 1999), anti-inflammatory (Wade et al., 1982), antitumour (Demirbaş et al., 2002), antimicrobial (Demirbaş et al., 2005), and antiviral (Kritsanida et al., 2002). Several compounds containing an 1,2,4-triazole ring, for example fluconazole and itraconazole, are well known drugs. 1,2,4-Triazol-3-one drugs such as trazodone- $\mathrm{HCl}$ [2-\{3-[4-(3-chlorophenyl)-1-piperazinyl]propyl\}1,2,4-triazol-[4,3- $\alpha$-pyridin-3-(2H)-one hydrochloride] (Brodgen et al., 1981), nefazodone- $\mathrm{HCl}$ [2-\{3-[4-(3-chlorophenyl)-1-piperazinyl]propyl\}5-ethyl-2,4-dihydro-4-(2-phenoxyethyl)-3H-1,2,4triazol-3-one hydrochloride] (Davis et al., 1997), and etoperidone-HCl [2-\{3-[4-(3-chlorophenyl)1-piperazinyl]propyl\}-4,5-diethyl-2,4-dihydro-3H1,2,4-triazol-3-one hydrochloride] (Ramacci et al., 1979) are known for their therapeutic use in treating depression. These drugs selectively block postsynaptic serotonin 5-hydroxytryptamine (5-HT) receptors (Rafa et al., 1992). Additionally, pyrrole and its derivatives have shown to possess biological activities such as antibacterial (Demirayak et al., 1999), antitumour (Halazy and Magnus, 1984), and antitubercular (Sbardella et al., 2004).
In view of the pharmacological profiles of the two chemical moieties described above, we synthesized hybrid compounds that comprise both the pyrrole and the 1,2,4-triazol-5-one ring system. The synthesis, determination of lipophilicity and antibacterial activities were described earlier (Pitucha el al., 2009). This paper reports results of preliminary pharmacological investigations of the synthesized compounds. In particular, some behavioural tests were performed in order to check the influence of derivatives of 1,2,4-triazol-5-one on the central nervous system (CNS) of mice.

\section{Results and Discussion}

3-[(1-Methylpyrrol-2-yl)methyl]-4-substituted 4,5-dihydro-1 $H$-1,2,4-triazol-5-ones were obtained by the intramolecular dehydrative cyclization reaction of 1-[(1-methylpyrrol-2-yl)acetyl]-4-substituted semicarbazides in basic medium (Pitucha et al., 2009). The chemical strucures of the investigated compounds are shown in Fig. 1.

Preliminary pharmacological studies showed that these derivatives of 1,2,4-triazol-5-one have a slight depressive effect on the CNS of mice. All tested compounds prolonged the thiopentalinduced sleep but only when administered in a dose of $100 \mathrm{mg} / \mathrm{kg}$ i.p. (Table I). None of the compounds had a neurotoxic effect because they did not disturb motor coordination in the "chimney test" in mice. 
<smiles>[R]n1c(Cc2cccn2C)n[nH]c1=O</smiles>

$$
\begin{aligned}
& \text { 1: } \mathrm{R}=4-\mathrm{BrC}_{6} \mathrm{H}_{4} \\
& \text { 2: } \mathrm{R}=\mathrm{C}_{6} \mathrm{H}_{11} \\
& \text { 3: } \mathrm{R}=\mathrm{C}_{2} \mathrm{H}_{5}
\end{aligned}
$$

Fig. 1. Chemical structures of compounds $\mathbf{1 - 3}$.

Compounds $\mathbf{1 - 3}$, differing in the substituents at position 4 of the triazole ring, showed analgesic effects. Compound 2 [4-cyclohexyl-3-[(1-methylpyrrol-2-yl)methyl]-4,5-dihydro-1 $H$-1,2,4-triazol- 5-one] was most active. In a wide dose range, it lowered the pain reactivity of mice in the "writhing syndrome" test (Table II). Compounds $\mathbf{2}$ and $\mathbf{3}$, at a dose of $100 \mathrm{mg} / \mathrm{kg}$ i.p., showed an anticonvulsive effect as they reduced the number of mice reacting with tonic seizures (Table III). Compound $\mathbf{3}$ [4-ethyl-3-[(1-methylpyrrol-2-yl)methyl]-4,5-dihydro-1H-1,2,4-triazol-5-one] significantly decreased their mortality. None of the tested compounds at $100 \mathrm{mg} / \mathrm{kg}$ i.p. showed anxiolytic, antidepressant or antiserotoninergic activities.

In conclusion, we found that the analgesic effect of the tested compounds is interesting and should be examined in more detail.

Table I. The influence of compounds $\mathbf{1}-\mathbf{3}$ on thiopental-induced sleep $(N=8)$.

\begin{tabular}{lccc}
\hline Compound & Treatment & \multicolumn{2}{c}{ Sleeping time } \\
\cline { 3 - 4 } & {$[\mathrm{mg} / \mathrm{kg}$ i.p.] } & {$[\mathrm{min} \pm \mathrm{SEM}]$} & $(\%)$ \\
\hline Control & - & $30.5 \pm 3.3$ & $100.0 \pm 10.8$ \\
$\mathbf{1}$ & 50 & $36.6 \pm 8.1$ & $315.6 \pm 61 *$ \\
$\mathbf{2}$ & 100 & $96.2 \pm 18.6 *$ & $104.9 \pm 8.5$ \\
& 25 & $32 \pm 2.6$ & $407.8 \pm 18.3 *$ \\
Control & 50 & $124.4 \pm 5.6 *$ & $506.3 \pm 12.4 *$ \\
$\mathbf{3}$ & 100 & $154.4 \pm 3.8 *$ & $100.0 \pm 22.0$ \\
& - & $30.0 \pm 6.6$ & $154.8 \pm 23.7$ \\
& 25 & $46.4 \pm 7.1$ & $361 \pm 2.3 *$ \\
\end{tabular}

* $p<0.001$ vs. the control group.

Table II. The antinociceptive activity of compounds $\mathbf{1}-\mathbf{3}$ in the "writhing syndrome" test in mice $(N=8)$.

\begin{tabular}{lccc}
\hline Compound & $\begin{array}{c}\text { Treatment } \\
\text { [mg/kg i.p.] }\end{array}$ & Mean writhing number & Inhibition $^{\text {a }}(\%)$ \\
\hline Control & - & $26.8 \pm 5.3$ & 0 \\
$\mathbf{1}$ & 25.0 & $17.8 \pm 5.8$ & 33.6 \\
& 50.0 & $15.8 \pm 1.3^{*}$ & $58.9^{*}$ \\
$\mathbf{2}$ & 100.0 & $7.4 \pm 2.5^{*}$ & $72.4^{*}$ \\
& 6.25 & $22.5 \pm 5.6$ & $40^{*}$ \\
& 12.5 & $16.0 \pm 1.8^{*}$ & $67.9^{*}$ \\
& 25.0 & $8.6 \pm 2.1^{*}$ & $92.2^{*}$ \\
Control & 50.0 & $2.1 \pm 0.9^{*}$ & $93.7^{*}$ \\
$\mathbf{3}$ & 100.0 & $1.7 \pm 0.2^{*}$ & 0 \\
& - & $28.6 \pm 5.3$ & 19.2 \\
& 12.5 & $23.1 \pm 8.4$ & $59.1^{*}$ \\
\end{tabular}

a \% of inhibition obtained by comparison with the control group.

* $p<0.001$ vs. the control group. 
Table III. The influence of the investigated compounds 1-3 on pentetrazole-induced convulsions in mice $(N=$ $8)$.

\begin{tabular}{lccc}
\hline Compound & $\begin{array}{c}\text { Treatment } \\
{[\mathrm{mg} / \mathrm{kg} \text { i.p. }}\end{array}$ & $\begin{array}{c}\text { Tonic seizure } \\
(\%)\end{array}$ & $\begin{array}{c}\text { Lethality } \\
(\%)\end{array}$ \\
\hline Control & - & 75 & 50 \\
$\mathbf{1}$ & 100.0 & 62.5 & 37.5 \\
$\mathbf{2}$ & 50.0 & 87.5 & 75 \\
& 100.0 & $37.5^{*}$ & $25^{*}$ \\
$\mathbf{3}$ & 50.0 & 87.5 & 75 \\
& 100 & $25^{*}$ & 75 \\
\hline
\end{tabular}

* $p<0.05$ vs. the control group.

\section{Experimental}

\section{Animals}

The study was performed on male Albino Swiss mice $(22-25 \mathrm{~g})$ purchased from a licensed dealer (Górzkowska, Warsaw, Poland). They were kept in colony cages with free access to tap water and food (standard laboratory pellets; Bacutil, Motycz, Poland) and maintained under a natural day-night cycle. The experiments were performed between 8 a.m. and 3 p.m. All the experiments were approved by the Ethical Board of the Medical University of Lublin, Poland. The investigated compounds 1-3 were administered intraperitoneally (i.p.) in doses of $6.25,12.5,25,50$, and $100 \mathrm{mg} /$ $\mathrm{kg}$ as suspensions in $1 \%$ aqueous Tween 80 solution at a constant volume of $0.1 \mathrm{ml}$ per $10 \mathrm{~g}$ body weight of mice. Control animals received the same volume of solvent. Each experimental group consisted of eight animals.

\section{Motor coordination in the "chimney test" (Boisser et al., 1960)}

Briefly, mice had to climb up backwards in a plastic tube ( $3 \mathrm{~cm}$ inner diameter, $25 \mathrm{~cm}$ long). Mice unable to perform the task within $60 \mathrm{~s}$ were considered to display motor impairment. Motor impairment was quantified as the percentage of animals that failed to complete the test.

\section{Body temperature}

The rectal body temperatures of mice (measured with an Ellab thermometer) were recorded $15,30,45,60,90$, and $120 \mathrm{~min}$ after injection of the investigated compounds in a dose of $100 \mathrm{mg} /$ kg i.p.

\section{Anxiolytic activity in the "four plate" test} (Aron et al., 1971)

The anxiolytic activity was assessed $30 \mathrm{~min}$ after administration of $\mathbf{1 - 3}$ in a dose of $100 \mathrm{mg} / \mathrm{kg}$ i.p. The number of punished crossings was counted for $1 \mathrm{~min}$.

\section{Immobilization time in the despair test (Porsolt et al., 1977)}

The compounds 1-3 were given in dose of $100 \mathrm{mg} / \mathrm{kg}$ i.p. before the testing. Mice were individually placed and forced to swim in a glass beaker ( $27 \mathrm{~cm}$ height, $16 \mathrm{~cm}$ diameter) containing $15 \mathrm{~cm}$ of water $\left(25^{\circ} \mathrm{C}\right)$. A mouse was considered immobile when it floated in the water, in upright position, and made only small movements to keep its head above the water. The total immobility time of mice was measured during the last 4 min of the 6-min test.

\section{Thiopental-induced sleep}

$60 \mathrm{mg} / \mathrm{kg}$ i.p. of thiopental (Sandoz, Vienna, Austria) were given $30 \mathrm{~min}$ after administration of $\mathbf{1 - 3}$ in doses of 50 and $100 \mathrm{mg} / \mathrm{kg}$ i.p.. The period during which the animals lost the righting reflex was regarded as the sleeping time.

Analgesic activity in the "writhing syndrome" test (Witkin et al., 1961)

Pain reactivity was measured in mice by the "writhing syndrome" test. $30 \mathrm{~min}$ after administration of $\mathbf{1 - 3}$ in doses of $100,50,25,12.5$ or $6.25 \mathrm{mg} / \mathrm{kg}$ i.p., the animals were injected i.p. with $0.6 \%$ acetic acid and the number of writhing episodes was counted for $30 \mathrm{~min}$.

\section{Pentetrazole-induced seizures}

30 min after administration of compounds $\mathbf{1 - 3}$ in a dose of $100 \mathrm{mg} / \mathrm{kg}$ i.p., the mice were injected subcutaneously (sc) with pentetrazole $(115 \mathrm{mg} / \mathrm{kg})$. Right afterwards the animals were placed singly in organic cages $(25 \times 15 \times 10 \mathrm{~cm})$. The clonic and tonic seizures as well as mortality were recorded for $30 \mathrm{~min}$. 
Head-twitch responses induced by

5-hydroxytryptophan (5-HTP)

(Corne et al., 1963)

The tested compounds $\mathbf{1 - 3}$ in a dose of $100 \mathrm{mg} /$ $\mathrm{kg}$ i.p. were administered $30 \mathrm{~min}$ before of 5-HTP in a dose administration of $180 \mathrm{mg} / \mathrm{kg}$. Immediately after the treatment the mice were separated in organic glasses and the number of head-twitch episodes was counted for $60 \mathrm{~min}$.

Aron C., Simon P., Larousse C., and Boissier J. R. (1971), Evaluation of a rapid technique for detecting minor tranquilizers. Neuropharmacology 10, 459-469.

Boisser J. R., Tardy J., and Diverres J. C. (1960), Une nouvelle méthode simple pour explorer l'action tranqiulliante: le test de la chemine. Med. Exp. 3, 81-84.

Bordgen R. N., Hell R. C., Speight T. M., and Avery G. S. (1981), Trazodone: A review of its pharmacological properties and therapeutic use in depression and anxiety. Drugs 21, 401.

Corne S. J., Pickering R. W., and Warner B. T. (1963), A method for assessing the effects of drugs on the central actions of 5-hydroxytryptamine. Br. J. Pharmacol. Chemother. 20, 106-120.

Davis R., Whittington R., and Bryson H. M. (1997), Nefazodone: a review of its pharmacology and clinical efficacy in the management of major depression. Drugs 53, 608.

Demirayak S., Karaburun A. C., and Kiraz N. (1999), Synthesis and antibacterial activities of some 1-[2-(substituted pyrrole-1-yl)ethyl]-2-methyl-5-nitroimidazole derivatives. Eur. J. Med. Chem. 34, 275-278.

Demirbaş N., Ugurluoglu R., and Demirbaş A. (2002), Synthesis of 3-alkyl(aryl)-4-alkylidenamino-4,5-dihydro-1H-1,2,4-triazol-5-ones and 3-alkyl-4-alkylamino-4,5-dihydro-1H-1,2,4-triazol-5-ones as antitumor agents. Bioorg. Med. Chem. 10, 3717-3723.

Demirbaş N., Demirbaş A., and Karaoğlu Ş. A. (2005), Synthesis and biological activities of new 1,2,4-triazol-3-one derivatives. Russ. J. Bioorg. Chem. 31, $387-397$.

Halazy S. and Magnus P. (1984), Studies on the antitumor agent CC-1065: 1-phenylsulfonyl-1,3-butadiene - an electrophilic equivalent to 1,3-butadiene for the synthesis of 3,3'-bipyrroles. Tetrahedron Lett. 25, $1421-1424$.

Kane J.M., Baron B.M., Dudley M.W., Sorensen S.M., and Staegen M.A. (1990), 2,4-Dihydro-3H-1,2,4-triazol-3-ones as anticonvulsant agents. J. Med. Chem. 33, 2772-2777.

Kritsanida M., Mouroutsou A., Marakos P., Pouli N., Papakonstantinou-Garoufalias S., Pannecouque C.,

\section{Statistical analysis}

The Student $t$-test (for analyzing the data from Tables I and II ) or the Fisher two-tailed exact probability test (for analyzing the data from Table III) were used to determine the significance of differences between mean values of the control and investigated groups. Differences were considered significant when $p<0.05$.

Witvrouw M., and De Clercq E. (2002), Synthesis and antiviral activity evaluation of some new 6-substituted 3-(1-adamantyl)-1,2,4triazolo[3,4- $b][1,3,4]$ thiadiazoles. Farmaco 57, 253-257.

Pitucha M., Polak B., Świeboda R., Kosikowska U., and Malm A. (2009), Determination of lipophilicity of some new derivatives of semicarbazide and 1,2,4-triazol-5-one with potential antibacterial activity. Z. Naturforsch. 64b, 570-576.

Porsolt R. D., Bertin A., and Jalfre M. (1977), Behavioral despair in mice: a primary screening test for antidepressants. Arch. Int. Pharmacodyn. Ther. 229, 327-336.

Rafa R. B., Shank R. P., and Vaught J. L. (1992), Etoperidone, trazodone and MCPP: in vitro and in vivo identification of serotonin 5-HT1A (antagonistic) activity. Psychopharmacology 108, 320.

Ramacci M. T., Ghirardi O., Maccari F., Pacifici L., and Sale P. (1979), Pharmacological evaluation of $\Delta^{2}$-1,2,4-triazolin-5-one[1,3-(4- $m$-chlorophenyl-1-piperazinyl)propyl]-3,4-diethyl-hydrochloride (etoperidone), a new potential antidepressant drug. Arzneim.Forsch. Drug Res., 29, 294-307.

Sbardella G., Mai A., Artico M., Loddo R., Setzuc M. G., and Collac P. L. (2004), Synthesis of new 4-pyrrol-1yl benzoic acid hydrazide analogs and some derived oxadiazole, triazole and pyrrole ring systems: A novel class of potential antibacterial and antitubercular agents. Bioorg. Med. Chem. Lett. 14, 1537-1541.

Turan-Zitouni G., Kaplancikli Z. A., Erol K., and Kiliç F. S. (1999), Synthesis and analgesic activity of some triazoles and triazolothiadiazines. Farmaco 54, 218-223.

Wade P. C., Vogt B. R., Kissick T. P., Simpkins L. M., Palmer D. M., and Millonig R. C. (1982), 1-Acyltriazoles as antiinflammatory agents. J. Med. Chem. 25, $331-333$.

Witkin L., Heubner G., Galdi F., O'Keefe E., Spitaletta F., and Plumer A. (1961), Pharmacology of 2-aminoindate hydrochloride (SU-8629): A patent non-narcotic analgesic. J. Pharmacol. Exp. 133, 400-408. 